\title{
The Impact of Leadership Styles on Employee Organisational Commitment in Higher Learning Institutions
}

\author{
Munyeka Wiza ${ }^{1}$ \\ Ngirande Hlanganipai ${ }^{2}$ \\ Department of Business Management, University of Limpopo (Turfloop Campus), \\ Private Bag 1106. Sovenga, 0727. South Africa \\ E-mail addresses: masterwiza2000@yahoo.com¹,hlanganipai@yahoo.com²
}

\author{
Doi:10.5901/mjss.2014.v5n4p135
}

\begin{abstract}
The current study seeks to determine the impact of leadership styles on employees' organisational commitment constructs among University academic staff at a selected South African institution. A quantitative methodology, using self-administered surveys comprised of the Organisational Commitment Questionnaire (OCQ) and the Multi Factor Leadership Questionnaire (MLQ) was used to collect data from 160 respondents. The data was analysed using Statistical Package for the Social Sciences (SPSS), version 20.0. Spearman correlation analysis was used to test for relationships between the independent variable (leadership style) and the dependant variable (organizational commitment. The findings of the study revealed that transformational leadership style has a significant and positive relationship with affective and continuance employee commitment while transactional leadership style has significant and positive relationship with only normative commitment. Based on the findings of this study, it is worth noting that leadership styles plays an important role to an employees' organizational commitment and it is very important for organizational policy makers to take this into consideration in order to meet organizational goals. This study contributes to the bank of findings relating to the development of leadership and organisational commitment, not only in South Africa, but within the institutions of higher learning in particular.
\end{abstract}

Keywords: Impact, Academics, Transformational leadership, Transactional leadership, Organisational commitment.

\section{Introduction}

Leadership is a topic with a broad appeal as most of the people are consciously or unconsciously involved in the process of being influenced or influencing others in the role of leadership. People are always interested in knowing the components that contribute to making an ordinary person a great leader (Bateman \& Snell, 2002). There are various forms of leadership styles. However for the sake of this study, only two forms of leadership styles (i.e. transformational and transactional leadership) were used. Transactional leadership is defined as the interaction between leaders and followers (Marturano \& Gosling, 2007).

Bass (1985) described transactional leadership in terms of two characteristics: the use of contingent rewards and management by exception. They described contingent reward as the reward that the leader will bestow on the subordinate once the latter has achieved goals that were agreed to. Contingent reward is, therefore, the exchange of rewards for meeting agreed-on objectives. By making and fulfilling promises of recognition, pay increases and advancement for employees who perform well, the transactional leader is able to get things done. Bass (1985) therefore argues that by providing contingent rewards, a transactional leader might inspire a reasonable degree of involvement, loyalty and, commitment from subordinates. Transformational leadership according to Nyengane (2007) is when a leader ensures that followers are consciously aware of the importance of sharing organisational goals and values. They also find ways to ensure that followers know how to achieve these goals.

The field of education is facing a lot more challenges in making its employees committed to the organization (Jones, 2000). According to Gunter (2001) the responsibility of education leadership is to facilitate the learning activities and provide an environment that is enabling and supportive for knowledge and related activities. Butcher, Moon and Bird (2000) recognized the importance of leadership for professional development in education.

Committed employees are less likely to develop patterns of tardiness or to be chronically absent from work (Davenport, 2010). Gbadamosi (2003) contends that the more favourable an individual's attitudes toward the organisation, the greater the individual's acceptance of the goals of the organisation, as well as their willingness to exert 
more effort on behalf of the organisation.

Employees that are committed are also less likely to leave the organisation to explore other. Therefore, carrying out a study of this nature will be important in trying to find out it is the case.

Previous researches regarding leadership and organisational commitment has also been conducted among participants from various cultural backgrounds and understandably researchers came up with inconclusive results on the relationship between the leadership styles and employee organizational commitment (Takao, 1998; Wang, 2004). In addition, though the literature suggests a relationship between leadership style and organisational commitment, empirical studies are limited and lack specificity concerning types of leadership styles and organisational commitment (Rai \& Sinha, 2000; Yousef, 2000). Different styles of leadership such as transformational and transactional leadership styles and their impact on employee organisational commitment have not been fully discussed especially in higher learning institutions in the South African context. Therefore this study seeks to investigate the impact of leadership style on employee organisational commitment among higher learning academic staff at a selected South African institution.

\section{Objectives of the Study}

The objectives of this study were:

- To investigate the impact of leadership styles (transformational and transactional leadership) and employee organisational commitment.

- To give recommendations to the management on leadership strategies that can be used to improve employee organisational commitment in the organization based on the research findings.

\section{Research Hypothesis}

- H1. There is a positive relationship between transformational leadership and employees' organisational commitment (i.e. affective, continuance and normative commitment) among academic staff.

- $\quad$ H2. There is a positive relationship between transactional leadership and employees' affective, continuance and normative commitment among academic staff.

\section{Literature Review}

\subsection{Theoretical framework}

The study utilized Grint (2000)s' trait, contingency and situational approaches which are constrained by some form of essentialism and determinism whereby leadership is seen to be determined by personality (trait), the environment (situational) or by matching the appropriate traits to different environments (contingency) as depicted in figure 1 below.

Figure 1: Essentialist and non-essentialist leadership

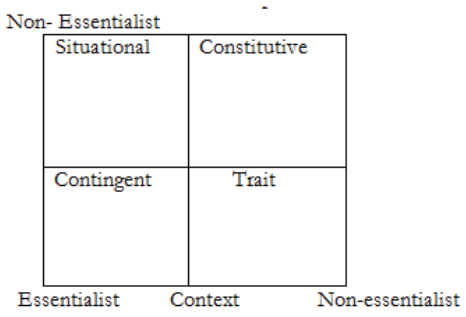

According (Grint, 2000) the trait approach concentrates on the qualities of the individual as essential and universal aspects of leadership regardless of diverse contexts. Leadership is seen as almost equivalent to personality and cannot therefore be taught or improved. By contrast, the situational approach perceives the context as essential but the qualities of the individual leader is less relevant. The approach ague that there are no universal styles of leadership for it will change depending on the circumstances, context or situation. Once the situation is defined, leaders can be taught the appropriate skills necessary to lead in particular contexts that it is presumed are readily captured through their essential 
features.

Particular leaders could grow into the job assuming a competent analysis that discloses the essence of the situation. The exact opposite of this is the contingency approach where you have to match the right leader for each circumstance or contingency rather than secure his or her adaptation to the environment.

In addition to approaches' essentialism and determinism, it is our view that these leadership theories tend to reflect and reproduce the autonomous subject of enlightenment thinking since leadership is invariably seen to be the property of individuals and also not that of social groups or institutions. This is less so for the constructionist approach, where the argument is that leadership is about neither an essential individual nor an essential context but an outcome of interpretation (Grint, 2000). Within such a framework, leadership would simply be the embodied manifestation of collective and communal interpretations of appropriate behaviour in particular contexts. Grint (2000) further states that the constitutive approach eschews any sense of essential characteristics or contexts in favour of understanding interpretation to be at the centre of practical leadership.

\subsection{The concept of Leadership}

Leadership is one of the world's oldest and most topical issues. The importance of good leadership in producing what is required of an organization is accepted unquestionably, from corporate enterprises to educational institutions. Its key role within the changing education systems of different countries has acknowledged over the past decade or so. Leadership is believed to exist in at every level throughout an organization and usually includes management tasks. Leadership has been given different definitions by different authors. Kotter (1988) views it as the process of influencing people to strive willingly to achieve goals. The goals, or movement in a particular direction, should be in the long term interest of the group being led. Kouzes and Posner (1997) in Chipunza (2006: 11) define it as the "art of mobilizing others to want to struggle for shared inspirations". Chipunza (2006) pointed out that both these definitions observe that there is an important interpersonal process that takes place between leaders and individuals and groups of individuals towards the purposeful pursuance of objectives. The above conceptualizations of leadership indicate the importance of developing leadership that promotes co-operation, trust and commitment between the followers and the leaders in organizations.

\subsection{Understanding the concept of Organizational commitment.}

Organizational commitment is defined in multiple ways. Organizational commitment refers to the employee's emotional attachment to, identification with, and involvement in the organization and it is generally considered as a three dimensional construct comprising affective commitment, continuance commitment and normative commitment (Boehman, 2006). Muchinsky (2003) adds that the concept of organizational commitment refers to the extent to which an employee feels a sense of allegiance to his or her employer organization. Werner (2007: 14) indicates that "an employee who is engaged to the organization is emotionally, cognitively and personally committed to the organization and its goals by exceeding the basic requirements and expectations of the job".

According to Meyer and Allen (1991) there are three-components of organisational commitment which are: 1. Affective commitment which involves the employee's emotional attachment to, identification with, and involvement in the organization. 2. Continuance commitment which involves commitment based on the costs that the employee associates with leaving the organization and, 3 . Normative commitment which involves the employee's feelings of obligation to stay with the organization. Given this, one can argue that organisational commitment is an attitude about an employee's loyalty to his organization and is an ongoing process through which organisational participants express their concern for the organization as well as its continued success and wellbeing.

\subsection{Leadership styles and Organizational commitment relationships}

According to Nyengane (2007), employee commitment reflects the quality of the leadership in the organisation. Therefore it is logical to assume that leadership behaviour would have a significant relationship with the development of organisational commitment. Previous researches suggest a positive direct relationship between leadership behaviour and organisational commitment.

Transformational leadership is generally associated with desired organisational outcomes such as the willingness of followers to expend extra effort (Bass, 1985). A willingness to expend extra effort indicates some degree of commitment. Contingent reward behaviours that represent transactional leadership have been found to be reasonably 
associated with performance and work attitudes of followers although at a lower level than transformational leadership behaviours (Nyengane, 2007).

A relationship between commitment and leadership style has been reported in the organisational and management literature. Nyengane (2007) reported a positive relationship between leader support and commitment. In three separate studies, Popper, Mayseless and Castelnovo (2000) in Nyengane (2007) found evidence to support the hypothesis that a positive correlation existed between transformational leadership and attachment. Kent and Chelladurai (2001) found that individualised consideration has positive correlation with both affective commitment and normative commitment.

Hayward, Goss and Tolmay (2004) also found that transformational leadership has moderate positive correlation with affective commitment. Lower correlation coefficients between transformational leadership and normative, as well as continuance, commitment were found. No correlation was found between transactional leadership and affective, normative and continuance commitment.

According to Walumbwa and Lawler (2003), there is considerable research available suggesting that the transformational leadership style is positively associated with organisational commitment in a variety of organisational settings and cultures. Nyengane (2007) indicated that transformational leaders are able to influence employees' organisational commitment by promoting higher levels of intrinsic value associated with creating a higher level of personal commitment on the part of the leader and followers to a common vision, mission, and organisational goals.

Transformational leaders influence followers' organisational commitment by encouraging them to think critically by using novel approaches, involving followers in decision-making processes and inspiring loyalty while recognizing and appreciating the different needs of each follower to develop his or her personal potential (Nyengane, 2007). By encouraging followers to seek new ways to approach problems and challenges and identifying with followers' needs, transformational leaders are able to motivate their followers to get more involved in their work, resulting in higher levels of organisational commitment (Walumbwa \& Lawler, 2003).

This view was supported by prior research that showed that organisational commitment was higher for employees whose leaders encouraged participation in decision-making (Nyengane 2007), emphasised consideration (Walumbwa \& Lawler, 2003) and were supportive and concerned for their followers' development (Allen \& Meyer, 1990).

\section{Research Methodology}

The quantitative research design was used in this study to investigate the impact of leadership styles on employee organisational commitment.

\subsection{Population and sample of the study}

The population consisted of academic staff members at a selected South African higher learning institution. Bless, Higson-Smith and Sithole (2013) defined population as the complete set of events, people or things to which the research findings are to be applied. In this study, the research population constituted of full time heads of departments, senior and junior lecturers including student's assistants.

To successfully conduct the research, stratified random sampling procedure was used. Stratified random sampling, according to Babbie (2013), is a modification of random sampling in which you divide the whole population into two or more strata based on one or more attributes. In this study, the participants were divided according to position levels (i.e. Heads of departments, senior lecturers, junior lecturers and student assistants. To ensure that samples adequately represent the relevant strata, 200 respondents were randomly selected from within each stratum.

\subsection{Instrumentation}

Two self-administered research questionnaires were used in this study. A 15 item Organisational Commitment Questionnaire with a 5 point likert scale ranging from strongly agree (SA) to strongly disagree (SD) was administered on the respondents to measure organisational commitment.

The shortened version of the Multifactor Leadership Questionnaire (MLQ) developed by Bass (1985) was used to measure both the transactional and transformational leadership style. The measuring instrument has 18 items and the participants were asked to rate their responses on a 5 point likert scale ranging from not at all (1) to frequently, if not always (5).

Scandura and Pilai (2001) confirmed the validity of the MLQ 5X. Using four different samples, Tejeda, Scandura, 
and Pilai (2001) found internal consistency coefficients (Cronbach Alphas) of between .85 and .90 for attributed charisma; between .86 and .91 for idealised influence; between 89 and .94 for inspirational leadership; between .86 and .91 for intellectual stimulation; between .86 and .93 for individual consideration; between .84 and .88 for contingent reward; between .69 and .79 for management by exception (active); between .82 and .90 for management by exception (passive) and $.72-.88$ for the non-management positions.

\subsubsection{Questionnaire administration}

Cover letters, affixed to the questionnaire, explaining the nature of the study, as well as assuring respondents of the confidentiality of any information were provided. Respondents were also provided with detailed instructions as to how the questionnaires were to be completed and returned. The rationale behind providing clear instructions and assuring confidentiality of information was based on the fact that this significantly reduces the likelihood of obtaining biased responses. Self-administered questionnaires were collected by the researchers over a period of two weeks. This method was considered the most efficient means of data collection since the sample was widely dispersed across the different faculties. A total of 200 questionnaires were administered, with 160 fully completed questionnaires being returned, thereby constituting an $80 \%$ return rate. This is higher than the 30\% anticipated in most research as put forward by Sekaran (2003).

\section{Data Analysis}

For the purposes of testing the research hypotheses, the returned questionnaires were inspected to determine their level of acceptability. They were coded. The data was transferred to an Excel sheet. A statistical computer package, Statistics Package for Social Sciences (SPSS) version 20.0 was used to process the results. Spearman product-moment correlation coefficient was used to measure the relationships between the variables, i.e. between leadership styles and employee organisational commitment.

\section{Research Findings}

\subsection{Sample Descriptive Summary}

Demographic data about the respondents shows that 90 (56\%) were females and $70(44 \%)$ were males. The majority $97(61 \%)$ of the participants were in the $36-50$ years. The majority of the respondents $89(56 \%)$ were junior lecturers, followed by senior lecturers $56(35 \%)$ and only $15(9 \%)$ were in the other category respectively.

Table 1: Demographic variables

\begin{tabular}{ccc}
\hline Variable & Frequency & Percentages \\
\hline Male & Gender & \\
Female & 90 & 56 \\
& 70 & 44 \\
& Age & \\
20-35 years & 46 & 29 \\
36-50 years & 97 & 61 \\
51-years and above & 17 & 10 \\
& Position & 56 \\
Junior lecturer & 89 & 35 \\
Senior lecturer & 56 & 9 \\
Other & 15 &
\end{tabular}




\subsection{Inferential Statistics (Hypothesis testing).}

Table 2: Relationship between leadership styles and organizational commitment dimensions

\begin{tabular}{|c|c|c|c|c|}
\hline \multirow{4}{*}{$\begin{array}{l}\text { Transformational } \\
\text { leadership style }\end{array}$} & & $\begin{array}{c}\text { Affective } \\
\text { commitment }\end{array}$ & $\begin{array}{l}\text { Continuance } \\
\text { Commitment }\end{array}$ & $\begin{array}{c}\text { Normative } \\
\text { Commitment }\end{array}$ \\
\hline & Pearson Correlation & $.301^{*}$ & $.682^{* \star}$ & .562 \\
\hline & Sig. (2-tailed) & .003 & .002 & .145 \\
\hline & $\mathrm{N}$ & 160 & 160 & 160 \\
\hline \multirow{3}{*}{$\begin{array}{l}\text { Transactional } \\
\text { leadership style }\end{array}$} & Pearson Correlation & .642 & .634 & $1.582^{\star}$ \\
\hline & Sig. (2-tailed) & .328 & .426 & 0.04 \\
\hline & $\mathrm{N}$ & 160 & 160 & 160 \\
\hline
\end{tabular}

In testing hypothesis 1 which stated that there is a positive relationship between transformational leadership and employees' organisational affective, continuance and normative commitment among academic staff, table 1 above presents the results of the relationships. Significant positive relationship was obtained between the transformational leadership style and affective commitment ( $r=.301, p=.003)$. Results also confirms a positive and significant relationship between transformational leadership style and continuance commitment $(r=.682, p=.002)$. However there was no significant relationship between transformational leadership style and normative commitment $(r=.562, p=.145)$. The results are supported by Hayward, Goss and Tolmay (2004) who also found that transformational leadership has positive correlation with affective and continuance commitment.

The second hypotheses examined whether there is a positive relationship between transactional leadership and employees' affective, continuance and normative commitment. The Pearson product moment correlation in table 1 revealed a weak but statistically significant relationship between transactional leadership and normative commitment( $r=1.582, p=.04)$. This implies that the as transactional leadership improves; the more employees are willing to remain/stay in the organization. The positive correlation between transactional leadership style and normative commitment suggests that leadership behaviors involving rewards, highlighting problems, and positive reinforcement related to how employees feel about ought to stay with the organization (Naidu \& Van Der Walt, 2005). This relationship also indicates that the leaders' and followers' associations affects employees' moral identification with an organization and relates to their feelings of responsibility (Allen \& Meyer, 1990). On the other hand, the absence of relationship for transactional leadership style with affective commitment and continuance commitment suggests that leadership behaviors involving exchange of rewards for meeting agreed-on objectives, highlighting problems, or waiting for problems to become serious before taking action, may not be related to how employees feel about want to stay and need to stay with the organization. These natures are more related with negative performance (Allen \& Meyer, 1990).

The results concur with the findings of Bučiūnienè and Škudienè (2008) which identified a significant and positive correlation between transactional leadership style and normative commitment though it does not confirm the relationship with that of affective and normative commitment by the same authors. Taken together, the research findings were also supported by previous studies of Bycio, Hackett and Allen (1995) [cited in Ponnu and Tennakoon, (2009); Lo, Ramayah and Min (2009) and Lo, Ramayah, Minc and Songand (2010) which indicated that transactional leadership has positive relationship with employees' organisational commitment.

The results seem understandable given that transactional leadership is based on an exchange of information between leaders and followers for various kinds of rewards. When this transactional relationship is acceptable to the follower, there may be a feeling of emotional attachment towards the organization. This could also possibly explain the non - significant correlation between transactional leadership and continuance commitment. Secondly, effective leaders typically display both transformational and transactional characteristics, as evidenced by the positive correlations between these two styles of leadership. This supports previous findings in the literature and suggests that effective executives use a combination of distinct leadership styles, each in the right measure and at the right time (Naidu \& Van Der Walt, 2005).

\section{Discussion}

The research objective of this study was to examine the impact of leadership styles on employee organisational 
commitment. Leadership literature suggested a positive relationship between transformational leadership and organisational commitment; however previous researchers (Judge \& Bono, 2000) have called for more research to support such a link. This study responds to this call and thus fills an important void in the leadership literature.

The findings are also consistent with previous studies (e.g., Garg \& Ramjee, 2013; Walumbwa and Lawler, 2003), that found a positive association between transformational leadership and organisational commitment. It is possible that close followers are more likely to see some of the inconsistencies in their leader's behavior, which may affect how committed they feel to the organization, as well as how empowered.

The findings as shown in table 1 suggest that there is a significant positive relationship between the transformational leadership style and both affective commitment and continuance commitment. On the other hand, there was a lack of statistically significant correlations between the transformational leadership and normative commitment; the findings suggest that this same leadership style may not be related to how employees feel about their obligation to stay with organization. In general, it may be concluded that respondents who are affectively committed to the organisation are more willing to maintain their relationship with the organisation than those who are normatively committed. Affectively committed employees will thus portray feelings of identification with the organisation, and attachment to and involvement in the organisation. This is in contrast with the dimension of normative commitment, which focuses on commitment by virtue a feeling of obligation to remain with the organisation.

The findings that transformational leadership style has no relationship with normative commitment may be also appropriate as Allen and Meyer 1990; Brooks et al. 2006 pointed out that employees who stay in the organization feel obligated to stay in the organization may not exhibit the same enthusiasm and involvement as employees who stay with an organization because they want to stay and need to stay. This is also in line with the argument of Mannheim and Halamish (2008) that reveals that as transformational leadership is enacted, members of organizations no longer seek merely self - interest but that which is beneficial to the organization as a whole. As such, transformational leadership style may not be related to normative commitment as to affective and continuance commitment. This study, therefore, supports the suggestions by Brown and Dodd (2003) [cited in Bučiūnienè and Škudiené, 2008] that transformational leadership and affective commitment are correlated but not that of having with normative commitment and not having correlation with continuance commitment. Bučiūnienè and Škudienè (2008) also confirms that transformational leadership has a positive relationship with affective and continuance commitment but different for that of normative commitment. Contrary to this, Garg and Ramjee (2013) revealed that transformational leadership style has a positive relationship with normative commitment and a negative correlation with continuance commitment.

\section{Conclusion and Recommendations}

The aim of this research was primarily to determine the impact of leadership styles on employee organizational commitment and the result findings showed a positive relationship between leadership styles and some employee organisational commitment constructs. Given this one may conclude that effective leaders can positively influence trust and meaning within followers and in turn so motivate them to be willing to remain in the organization and feel part of it.

The problems of academics in careers with high levels of job dissatisfaction and work stress should be addressed more proactively and effectively, especially where young academics are concerned. The reason for this is that they are associated with, among others, decreased organisational commitment, decreased mental and physical health, problematic collegial relationships, and a decrease in the quality of work life. Pienaar (2005) feels strongly that, should such problems not be addressed, high quality academics will in all probability increasingly be lost for higher education and its institutions. If this institution does not take heed of the above and so continues to lose academics, its national and international image and its competitive advantage, as well as the ability to generate new knowledge in a specific field may be adversely affected.

Transformational leadership style positively relates to affective commitment and at the same time to continuance commitment, implying that the management must be mindful of the leadership styles on employee commitment. It can be concluded that employees who are under a good leader are more likely to identify themselves as part of the organization.

The existing leadership and employee organizational commitment research also suggests that the leadership style of leaders can lead to higher measures of organisational commitment in their direct reports. This study has demonstrated positive relationships between leadership styles and organisational commitment. Overall findings from this study suggest that transformational and transactional leadership behaviours do play important roles in determining levels of affective commitment, continuance commitment and normative commitment. 


\section{References}

Allen, N.J \& Meyer, J.P. (1990). The Measurement and Antecedents of Affective, Continuance and Normative Commitment to the Organisation. Journal of occupational Psychology, 63, 1-18.

Babbie, E.R. (2013). The Practice of Social Research. (14th edn.). Belmont, CA: Wadsworth.

Bagraim, J.J. (2003). The Nature of Measurement of Multiple Commitment Foci amongst South African Knowledge Workers. Management Dynamics, 12(2), 13-23.

Bass, B.M. (1985). Leadership: Good, Better, Best. Organisational Dynamics. 13(3), 26-40.

Bateman, T.S., \& Snell, S.A. (2002). Management: Competing in the New Era (5th Edition). The McGraw-Hill Companies Inc.

Bless, C., Higson-Smith, C., Sithole, S.L. (2013). Fundamentals of Social Research Methods: An African Perspective (5 $5^{\text {th }}$ edn.). Juta and Company Ltd. Cape Town.

Boehman, J. (2006). Affective, Continuance, and Normative Commitment among Student Affairs professionals, (unpublished doctoral dissertation) North Carolina State University, Raleigh, NC (ProQuest Digital Dissertations).

Brockner, J., Siegel, P.A., Daly, J.P., Tyler, T., \& Martin, C. (1997). When trust matters: The moderating effect of outcome favorability. Administrative Science Quarterly, 42, 558-583.

Bučiūnienè, I., Škudienè, V. (2008). Impact of Leadership Styles on Employees' Organisational Commitment in Lithuanian Manufacturing Companies. SEE Journal, 33, 57-65.

Bussing, A. (2002). Trust and its Relations to Commitment and Involvement in Work and Organisations. SA Journal of Industrial Psychology, 28(4), 36-42.

Butcher, J., Moon, B., \& Bird, E. (2000). Leading Professional Development in Education. Routledge. Falmer. London.

Chipunza, C. (2006). Transformational Leadership in merging tertiary institutions. (Unpublished Masters Dissertation). University of Fort Hare, South Africa.

Eid, J., Johnsen, B.H., Bartone, P.T., \& Nissestad, O.A. (2008). Growing Transformational Leaders: Exploring the Role of Personality Hardiness. Military Psychology, 23(4), Jul 2011, 381-389.

Garg, A. K, D. Ramjee, D. (2013). The Relationship between Leadership Styles and Employee Commitment at a Parastatal Company in South Africa. International Business \& Economics Research Journal, 12(11) 1411-1436.

Grint, K. (2000). The Arts of Leadership. Oxford University Press.

Gunter, H.M. (2001). Leaders \& Leadership in Education.Paul Chapman Publishing A SAGE Publication Company, 6 Bonhill Street, London.

Hayward, Q., Goss, M., \& Tolmay, R. (2004). The Relationship between Transformational and Transactional leadership and employee commitment. Grahamstown: Rhodes University. Business Report.

Jones, B.A. (2000). Educational Leadership: Policy Dimensions in the 21st Century. Greenwood Publishing Group Inc. USA.

Judge, T. A., \& Bono, J. E. (2000). Five-factor model of personality and transformational leadership. Journal of Applied Psychology, 85 : 751-765.

Kent, A. \& Chelladurai, P. (2001). "Perceived transformational leadership, Organizational commitment, and citizenship behaviour: a case study in intercollegiate athletics". Journal of sport management, 15:135-159.

Kotter, J.P. (1988). The leadership factor. New York: the free press.

Lo, M., Ramayah, T., Min, H. (2009). Leadership styles and organisational commitment: A test on Malaysia manufacturing industry. African Journal of Marketing Management, 1, 133-139.

Lo, M., Ramayahb, T., Minc, H., \& Songand, P. (2010). The relationship between leadership styles and organisational commitment in Malaysia: Role of leader-member exchange. Asia Pacific Business Review, 16, 79-103.

Marturano, A. \& Gosling, J. (2007). Leadership: The key concepts. New York, NY: Routledge.

Naidu, J., \& Van Der Walt, M. S. (2005). An Exploration of the relationship between Leadership styles and the implementation of Transformation Interventions. South African Journal of Human Resource Management, 3 (2), 1-10.

Nyengane, M.H. (2007). The relationship between leadership style and employee commitment: an exploratory study in an electricity utility of south Africa. (Unpublished Masters of Business Administration, Rhodes University, South Africa.

Pienaar, J.W. (2005). Career Dilemmas of Academics within a Changing South African Higher Education Institution. (Unpublished doctoral thesis). Bloemfontein: University of the Free State.

Ponnu, C. H., \& Tennakoon, G. (2009). The Association between Ethical Leadership and Employee Outcomes. Electronic Journal of Business Ethics and Organization Studies, 14, 21-32.

Popper, M., Mayseless, O., \& Castelnovo, O. (2000)."Transformational leadership and attachment". Leadership Quarterly, $11(2): 267-$ 289.

Rai, S., Sinha, A. K. (2000). Transformational Leadership, Organisational Commitment and Facilitating Climate. Psychological Studies, 45 (1) 2: 33-42

Saunders, M., Lewis, P., \& Thornhill, A. (2003). Research Methods for Business Students (3rd edn.). England: Prentice Hall.

Scandura, T. A., \& Pillai, R. (2001). Charismatic leadership: A review, reanalysis, and integration of major theories. Academy of Management, Organisational Behavior Division, Boston, MA.

Takao, S. (1998). The Multidimensional of Organisational Commitment: An Analysis of its Antecedents and Consequences among Japanese Systems Engineers. Tokyo: institute for Economic \& Industry Studies, Keo University.

Tejeda, M.J., Scandura, T.A., \& Pillai, R. (2001). The MLQ revisited: Psychometric properties and recommendations. The Leadership 
Quarterly, 12, 31-52.

Vigoda, E., Cohen, A. (2003). Work Congruence and Excellence in Human Resource Management. Empirical Evidence from the Israeli Non - profit Sector. Review of Public Personnel Administration, 23, 192-216.

Walumbwa, F.O. \& Lawler, J.J. (2003). Building effective organizations: transformational leadership, collectivist orientation, work-related attitudes, and withdrawal behaviors in three emerging economies. International journal of human resource management, 14: 1083-1101.

Wang, R.F. (2004). Spatial representations and spatial updating. In D. E. Irwin, \& B. H. Ross (Eds.). The psychology of learning and motivation, 42: 109-156).

Werner, A. (2007). Organisational Behaviour: a Contemporary South African Perspective. Pretoria: Van Schaick.

Yousef, D.A. (2000). "Organisational commitment: a mediator of the relationships of leadership behavior with job satisfaction and performance in a non-western country". Journal of Managerial Psychology, 15 (1): 6-24. 